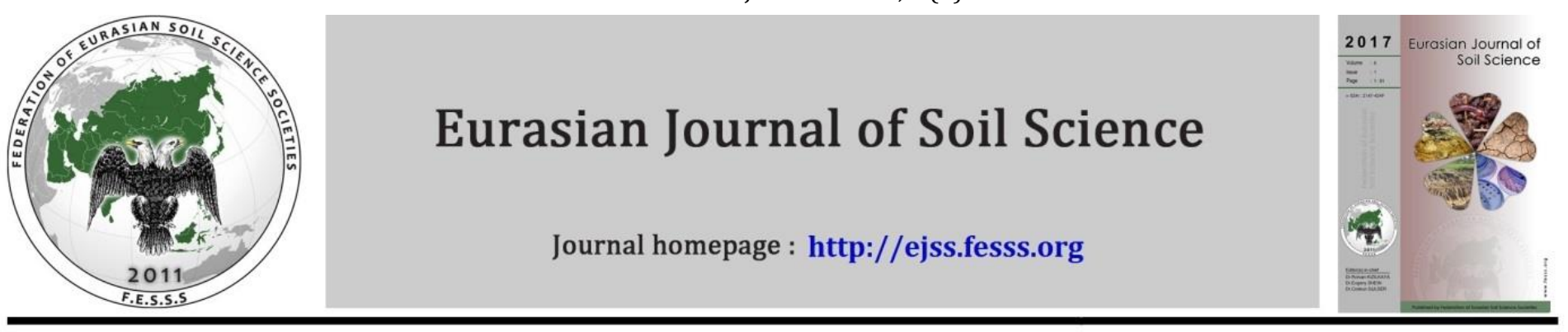

\title{
Effect of phosphorus solubilizing bacteria on some soil properties, wheat yield and nutrient contents
}

\author{
Ayten Namlı *, Ahmad Mahmood, Bahar Sevilir, Emre Özkır \\ Ankara University, Faculty of Agriculture Department of Soil Science and Plant Nutrition, Ankara, Turkey
}

\section{Article Info}

Received : 21.08 .2016

Accepted : 06.02.2017

\begin{abstract}
Application of chemical fertilizers besides economic concerns has been a reason of environmental and ecosystem degradation, so sustainable organic agriculture is becoming popular in researches and among farming communities. Phosphorus holds second position after nitrogen among macronutrients required for better plant growth and is needed in higher amounts. Meeting this high phosphorus input for better crop yields causes environmental problems like eutrophication, so phosphorus solubilizing bacteria (PSB) and plant growth promoting rhizobacteria (PGPR) are being emphasized to utilize phosphorus fixed in soil layers. This study was carried out to evaluate the effect of PSB on plant growth, soil biological properties including enzymes and soil respiration. Treatments including control, $50 \mathrm{mg} \mathrm{kg}^{-1}$ nitrogen, $50 \mathrm{mg} \mathrm{kg}^{-1}$ nitrogen and $12 \mathrm{mg} \mathrm{kg}^{-1}$ phosphorus applications reduced dosage of nitrogen $25 \mathrm{mg} \mathrm{kg}^{-1}$ with PGPR and $25 \mathrm{mg} \mathrm{kg}^{-1}$ nitrogen along with $0.12 \mathrm{~g}$ raw phosphate and PGPR. Results indicated that plant parameters like above and below ground plant biomasses (fresh and dry weight), plant nitrogen and phosphorus content were significantly enhanced in all the treatments when compared with the control. While soil pH in rhizosphere significantly increased with the treatments, bulk soil pH decreased with PGPR treatments when compared with all other treatments. EC values in rhizosphere and bulk soils were not significantly influenced with the treatments. Rhizospheric and bulk soil showed high amount of N, P and organic matter in PGPR treatments. Alkaline phosphatase and $\beta$ glucosidase activities were found significantly higher in the last treatment than the other treatments. Basal soil respiration was interestingly found higher in control soil but did not differ statistically from the other treatments. Concluding, application of PGPR with lower amounts of chemical fertilizers can reduce the use of chemical fertilizers and has also potential of improving soil health in long term aspects.
\end{abstract}

Keywords: Phosphorus solubilizing bacteria, rhizosphere, bulk soil, alkaline phosphatase, $\beta$-glucosidase, basal soil respiration.

(C) 2017 Federation of Eurasian Soil Science Societies. All rights reserved

\section{Introduction}

More food production is required for constantly increasing population but is limited by decreasing agricultural land due to urbanization pressure (Hamuda and Patkó, 2013) and other diverse factors. Meeting this required food without damaging the ecosystems is a major concern which has become more demanding these days. Use of chemical fertilizers is under continuous criticism because of their high losses and escape to environment due to different processes like denitrification in case of nitrogen and eutrophication in case of phosphatic fertilizers (Hamuda and Patkó, 2013). Along with ecosystem pollution, extensive use of mineral fertilizers is also leading to land degradation. These circumstances force us to adopt environment friendly and sustainable agriculture which is possible solely through use of organic and biofertilizers.

\footnotetext{
${ }^{*}$ Corresponding author.
}

Ankara University, Faculty of Agriculture Department of Soil Science and Plant Nutrition, Diskapi, Ankara, 06110 Turkey

Tel.: +903125961231

E-mail address: namli@ankara.edu.tr 
Phosphorus being macronutrient stands second in plant requirements after nitrogen and is involved in various metabolism activities within the plants. Plant available phosphorus is usually deficient in the soil because it is fixed in soil layers. (Wang et al., 2009; Shenoy and Kalagudi, 2005; Khan et al., 2009; 2014). This insoluble or fixed phosphorus is in different forms fixed with calcium $\left(\mathrm{Ca}_{3} \mathrm{PO}_{4}\right)_{2}$, aluminum $\left(\mathrm{Al}_{3} \mathrm{PO}_{4}\right)$ and iron $\left(\mathrm{Fe}_{3} \mathrm{PO}_{4}\right)$ and can be turned to soluble forms by P-solubilizing organisms (Gupta et al., 2007; Song et al., 2008; Sharma et al., 2013) where P-solubilizing soil microbes have gained importance because of their ability to mineralize complex compounds (Bishop et al., 1994; Ponmurugan and Gopi, 2006; Toro 2007; Wani et al., 2007a). Release of different organic acids by these microorganisms lead to acidification of microenvironments (Maliha et al., 2004) and consequently replacement of P ions with cations which finally is termed as phosphorus solubilization (Goldstein, 1994; Mullen, 2005; Trivedi and Sa, 2008).

Phosphorus solubilizing bacteria (PSB) hold most important position in P-solubilizing soil microbes due to their multifunctional capabilities. Along with enhancing phosphorus availability for the plants, some PSB are also responsible for production of siderophore (Tank and Saraf, 2003; Hamadali et al., 2008; Wani et al., 2008), indole acetic acid and gibberellin (Sattar and Gaur, 1987; Souchie et al., 2007), antibiotics (Lipping et al., 2008; Taurian et al., 2010), secondary metabolites (Wani et al. 2007b) and 1-aminocyclopropane-1carboxylate (ACC) deaminase enzyme (Glick et al., 2007). Use of PSB as biocontrol agents against soil borne pathogens have also been reported (Khan et al., 2002; Vassilev et al., 2006; Singh et al., 2010).

Rhizosphere is termed as the soil zone directly surrounding the roots (Walker et al., 2003) and also bioinfluenced zone (Hinsinger et al., 2008). Inhabiting maximum of soil microbes, rhizosphere also supports plant growth through supplying plant nutrients (Gianfreda, 2015). Among the rhizosphere abundant bacteria; genera Azotobacter, Bacillus, Beijerinckia, Burkholderia, Enterobacter, Erwinia, Flavobacterium, Microbacterium, Pseudomonas, Rhizobium and Serratia are thought to be most promising PSB (Bhattacharyya and Jha, 2012). Several reports of increased plant yield and soil health through application of PGPR importantly PSB have been published. Application of Pseudomonas spp. significantly enhanced plant growth parameters in soybean (Son et al., 2006), maize (Mehrvarz et al., 2008), wheat (Afzal and Bano, 2008; Majeed et al., 2015), barley (Cakmakci et al., 2007), tomato (Calvo et al., 2010), green gram and alpine Carex trees (Bartholdy et al., 2001). Improvement in soil nutrient content regarding nitrogen and phosphorus was observed with application of PGPR in barley (Cakmakci et al., 2007).

Some soil biological properties such as enzyme activities and respiration activity are used as bio-indicators for soil quality and health for environmental soil monitoring (Kızllkaya et al., 2004; Akça and Namlı, 2015). Basal soil respiration of soil microflora provides useful information on the physiological condition of the pedoecosystem even though it is a matter some controversy. This respiratory activity takes into account the use of energy by microflora and expresses the efficiency of organic carbon by soil microorganisms (Ananyeva et al., 2016). In the prsent study, soil enzymes respentative of $\mathrm{C}$ and $\mathrm{P}$ cycle were selected. Glucosidases are widely distributed in nature and their hydrolysis products as low molecular weight sugars are important source of energy for soil microorganisms. $\beta$-glucosidase catalyzes the hydrolysis of $\beta$-Dglucopyranoside and is one of the three or more enzymes involved in the saccharification of cellulose (Kizllkaya and Bayrakl, 2005). Phosphatase is an enzyme of great agronomic value because it hydroles compounds of organic phosphorus and transforms them into different forms of inorganic phosphorus, which are assimilable by plants. Variations in phosphatase activity apart from indicating changes in the quantity and quality of a soil's phosphorated substrates, are also a good indicator of its biological state (Aşkın and Kizılkaya, 2006).

Soil biologic properties including enzyme activities indicate comprehensive results regarding bacterial inoculation to the soil (Caravaca et al., 2003). Soil enzyme activity is used in monitoring soil nutrient concentration changes as a result of inoculants' interaction with indigenous microbial population (Naseby et al., 1998) and these enzymes can alter the availability of different nutrients to the plants (Gianfreda, 2015). Soil enzymes also serve as soil quality indices and help us measure soil quality indirectly (Karaca et al., 2011). Enhancement of SEA through application of PGPR and PSB has been reported. Increase in phosphatases and dehydrogenases was observed in rhizospheric soil of lettuce through application of PGPR, arbuscular mychorhiza and PSB alone or in consortium (Kohler et al., 2007). Dehydrogenase activity was increased in soybean rhizosphere by application of Pseudomonas spp (Sharma et al., 2011).

The objectives of the present study were to evaluate the effects of PSB/PGPR applications on i) some chemical (such as; $\mathrm{pH}, \mathrm{EC}$, organic matter, $\mathrm{N}$ and $\mathrm{P}$ ) and biological properties (such as; alkaline phosphatase activity, $\beta$-glucosidase activity and basal soil respiration) of rhizosphere and bulk soil, and ii) nutrient content and yield of wheat plant. 


\section{Material and Methods}

\section{Soil and PSB/PGPR}

The soil used in this experiment had $30.8 \%$ clay, 32.7\% silt, 36.5\% sand and classified as clay loam (CL). The $\mathrm{pH}$ in water was 7.9 , the oxidizable organic matter content was $1.1 \%$, the total $\mathrm{N}$ was $0.02 \%, \mathrm{NaHCO}_{3}$ extractable P was $6 \mathrm{mg} \mathrm{kg-1}$, the soil C:N ratio was 31.9. Bacillus sp. \#189 tested in the present study was obtained from Konbiyo R\&D Ltd. Co., Konya Technocity, Konya, Turkey, by Dr. M.Ogut. The bacteria used in this study were previously isolated from wheat rhizosphere, identified, and tested for their ability to solubilize $\mathrm{P}$ and to reduce $\mathrm{pH}$ in culture conditions and microcosms, and also identified and reported as phosphorus solubilizing bacteria (PSB) and plant growth promoting rhizobacteria (PGPR) by M.Ogut (Ogut et al., 2011; Ogut and Er, 2016).

\section{Counting and culturing PSB/PGPR}

The PSB were grown in liquid nutrient medium aerobically $(200 \mathrm{rpm})$ at $35^{\circ} \mathrm{C}$ for $24 \mathrm{~h}$. The bacterial cultures were mixed with sterile zeolite, and the mixtures were further incubated at $35^{\circ} \mathrm{C}$ for a week and dried in aseptic conditions. The numbers of the PSB were in the $10^{8} \mathrm{CFU} \mathrm{g}^{-1}$ as determined by plate count. $1 \mathrm{~g}$ dried PSB/PGPR added in sterile saline solution $(0.85 \% \mathrm{NaCl})$ and the bacterial density of each suspension was adjusted to be $10^{8} \mathrm{CFU} \mathrm{ml}{ }^{-1}$. Pure cultures of PSB-PGPR used for inoculation were grown in sterile saline solution $(0.85 \% \mathrm{NaCl})$. Unsterilized soil samples in the pots were innoculated with $1 \mathrm{~mL}$ of $10^{8} \mathrm{CFU} \mathrm{mL}^{-1}$ bacterial suspension 30 min before sowing under sterilized conditions.

\section{Greenhouse experiment}

Soil samples were air dried in a laboratory and sieved through a 2-mm screen. The soil sample $(2 \mathrm{~kg}$ airdried soil) was placed in 2,5 L cylindrical plastic pots. A pot experiment was carried out to investigate the effects of PSB/PGPR inoculation on some chemical and biological properties of rhizosphere and bulk soils, and nutrient content and yield of Spring Wheat (Triticum aestivum) plant in the greenhouse of Soil Science \& Plant Nutrition Department in Ankara University. The experiment was conducted with 5 treatments and four replications, and the pots were distributed in completely randomized plot design. Soil without PSB-PGPR inoculation was used as a control treatment.

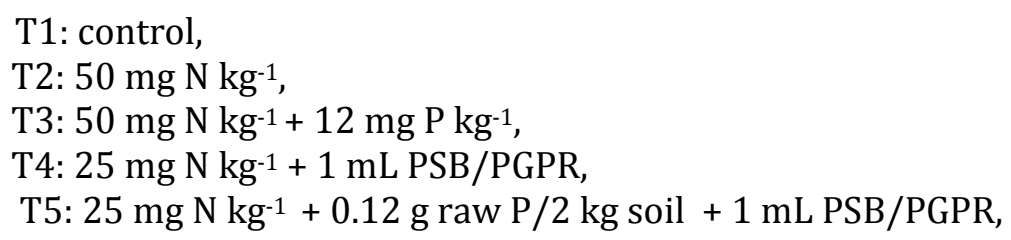

Ten seeds were sown in each pot and thinned to five plants per pot after the full emergence of the first leaf. The pots were regularly irrigated to maintain a proper moisture level. Plants in pots were harvested 80 days after sowing. The soils in pots were than moistened up to $70 \%$ of field capacity and maintained at this moisture throughout the experiment. At the end of the experiments, plant samples were collected from the pots. Studied plant parameters were shoot biomass, root biomass, N and P concentration in plants. All parameters were measured according to Ryan (2001).

\section{Soil analyses}

At the end of the experiment, soil samples were taken from each pot. Selected some chemical properties of rhizosphere and bulk soils were determined by the folowing methods; $\mathrm{pH}$ in 1: 2.5 (w:v) in soil:water suspension by pH-meter, electrical conductivity (EC) at the same suspension by EC-meter, soil organic matter by the wet oxidation method (Walkley-Black) with $\mathrm{K}_{2} \mathrm{Cr}_{2} \mathrm{O}_{7}$, total $\mathrm{N}$ by Kjeldahl method and available $\mathrm{P}$ by $\mathrm{NaHCO}_{3}$ extraction method (Rowell, 1996). Basal soil respiration (BSR), alkaline phosphatase activity (APA) and $\beta$-Glucosidase activity (GA) were determined according to the methods by Naseby and Lynch (1997).

\section{Statistical analysis}

One-way analysis of variance (ANOVA) was used to determine significant treatment effects at $5 \%$ significance level. Least significant difference (LSD) test was used to determine significant $(\mathrm{P}<0.05)$ differences. All statistical analyses were performed by statistix (Version 8.1). 


\section{Results}

\section{Chemical properties of rhizosphere and bulk soils}

The effects of different treatments on chemical properties of rhizosphere and bulk soils are illustrated in Figure 1. Rhizosphere soil $\mathrm{pH}$ was significantly affected by the treatments $(\mathrm{P}<0.05)$ which ranged from 7.71 to 7.89 where the lowest $\mathrm{pH}$ was recorded in the control and the highest was found in T3 which did not statistically differed from all other treatments, except the control.

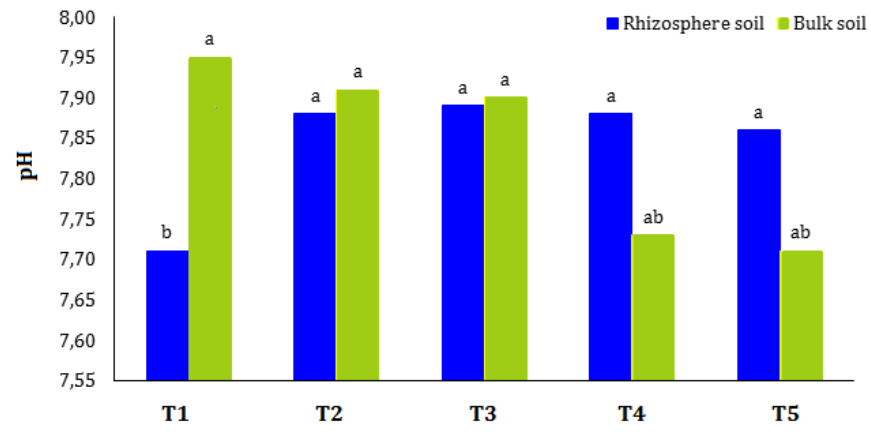

(a)

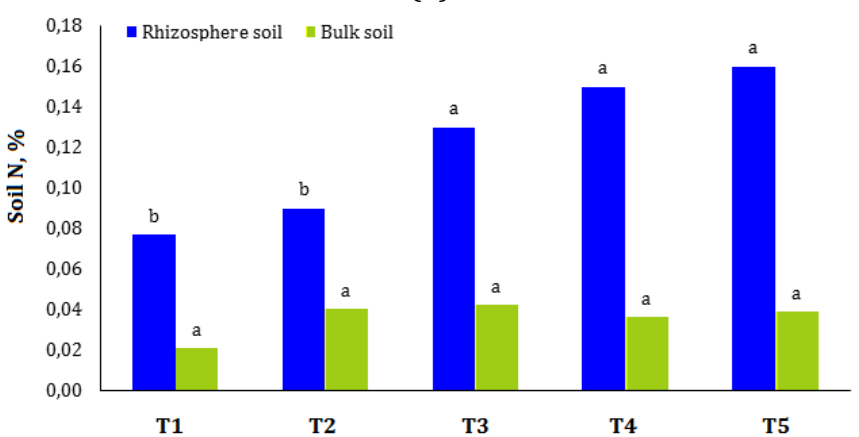

(c)

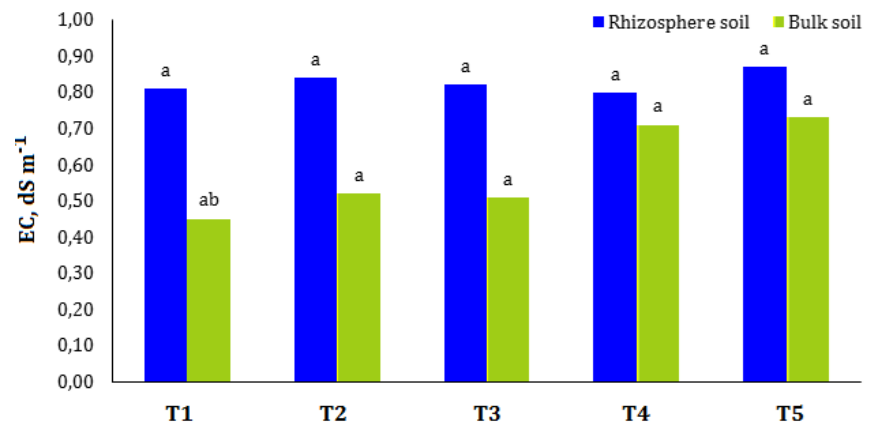

(b)

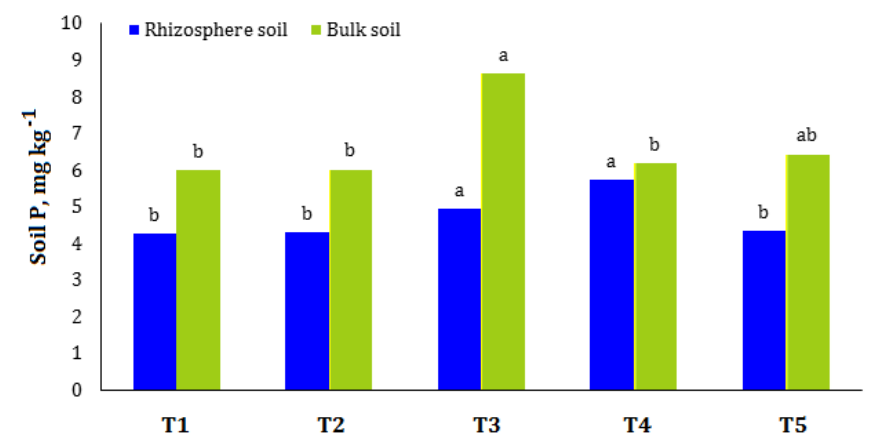

(d)

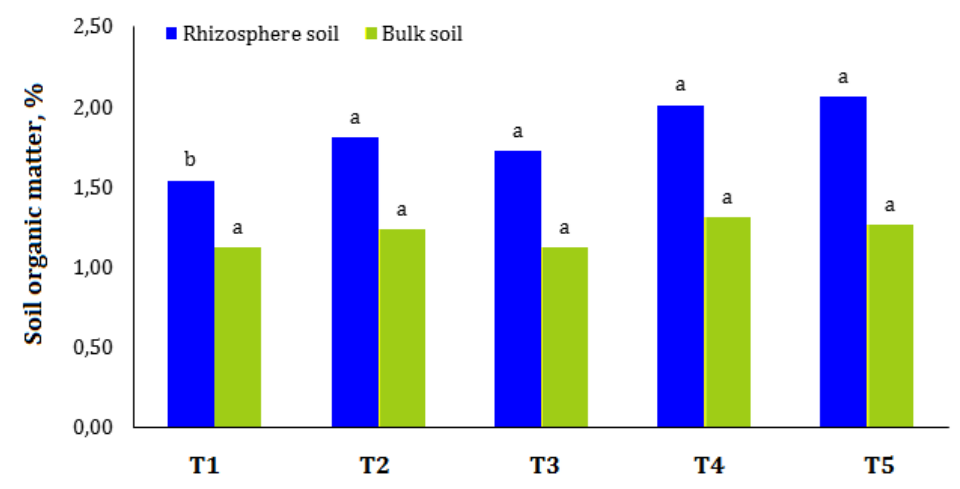

(e)

Figure 1. The effect of different treatments on chemical properties of rhizosphere and bulk soils

Bulk soil $\mathrm{pH}$ also significantly differed $(\mathrm{P}<0.05)$ within the treatments and ranged from 7.71 to 7.95 . The lowest $\mathrm{pH}$ was found in $\mathrm{T} 5$ which was not different from $\mathrm{pH}$ measured in T4 whereas the highest $\mathrm{pH}$ was found in the control which was similar with T2 and T3 (Figure 1a). Rhizosphere and bulk soil EC values were not significantly affected by the treatments (Figure 1b).

Rhizosphere soil $\mathrm{N}$ content was significantly affected by the treatments $(\mathrm{P}<0.05)$ and ranged from $0.077 \%$ to $0.16 \%$ where the lowest $\mathrm{N}$ content was found in the control and the highest one was found in T5 which was not significantly different from the values with $\mathrm{T} 3$ and $\mathrm{T} 4$ statistically. Bulk soil $\mathrm{N}$ content was not significantly affected by the treatments $(\mathrm{P}>0.05)$ and ranged from $0.021 \%$ to $0.042 \%$ where the lowest $\mathrm{N}$ was determined in the control which was statistically same with that in all other treatments (Figure 1c). 
Rhizosphere and bulk soil $\mathrm{P}$ content was significantly affected by the treatments applied $(\mathrm{P}<0.05)$. The rhizosphere $\mathrm{P}$ content ranged from 4.26 to $5.73 \mathrm{mg} \mathrm{kg}^{-1}$ where the lowest amount was observed in the control which was not different statistically from T2 and T5 treatments. The highest P content was calculated in T4 which was statistically the same with T3 treatment. Phosphorus content in bulk soil varied between 5.98 and $8.63 \mathrm{mg} \mathrm{kg}^{-1}$. The lowest $\mathrm{P}$ content was found in the control which was not significantly different from the values determined in $\mathrm{T} 2$, T4 and T5, while the highest $\mathrm{P}$ content was obtained in T3 treatment (Figure 1d).

Rhizosphere and bulk soil organic matter (SOM) contents followed similar trend. The treatments only affected the rhizosphere SOM content significantly $(\mathrm{P}<0.05)$ while the bulk SOM was not significantly affected ( $\mathrm{P}>0.05$ ). The rhizosphere SOM ranged from $1.54 \%$ to $2.06 \%$ among the treatments where SOM was increased significantly over control but did not differ significantly among the treatments of T2, T3, T4 and T5 (Figure 1e).

\section{Nutrient content and yield of wheat plant}

The effects of different treatments on nutrient content and yield of wheat plant are illustrated in Figure 2. Plant $\mathrm{N}$ content was significantly affected with the applications of different fertilizer sources $(\mathrm{P}<0.05)$ when compared with the control. Plant N content varied from $0.94 \%$ in the control to $1.52 \%$ in T2 treatment (Figure 2a). Plant $\mathrm{P}$ content was significantly affected by the treatments (P) and ranged from $0.10 \%$ to $0.21 \%$. The lowest $\mathrm{P}$ content was found in the control which was statistically the same with $\mathrm{T} 2$ and $\mathrm{T} 4$, and the highest P content was measured in $\mathrm{T} 3$ which was the same with T5 tatistically (Figure $2 \mathrm{~b}$ ).

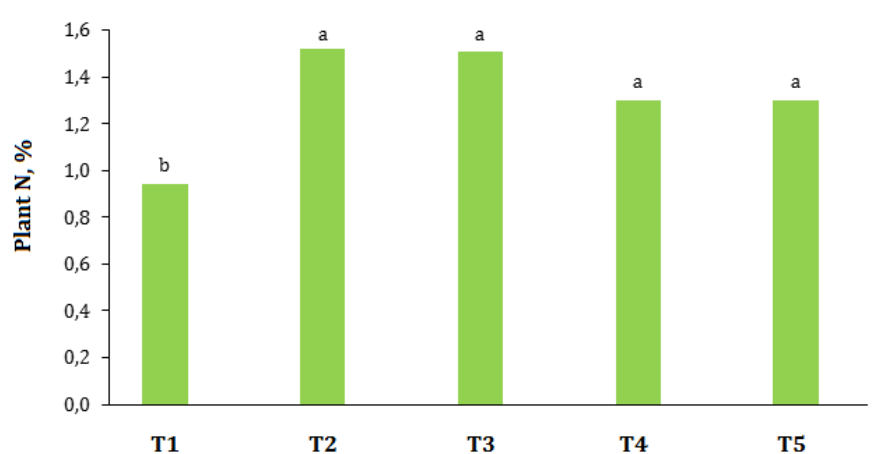

(a)

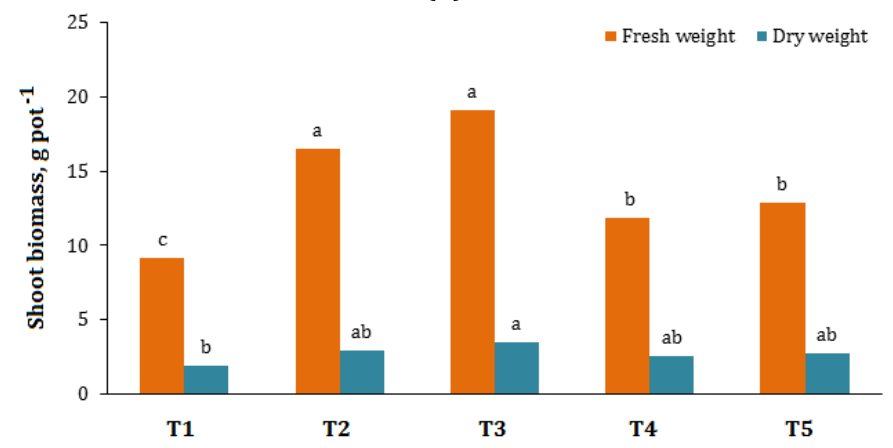

(c)

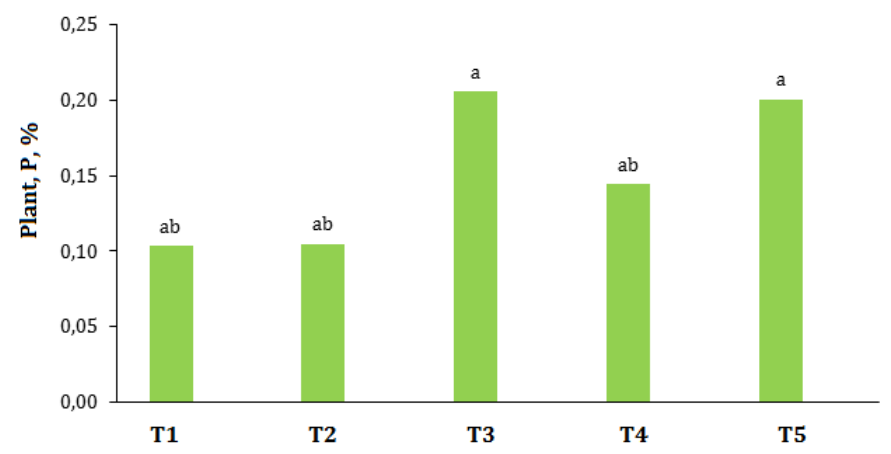

(b)

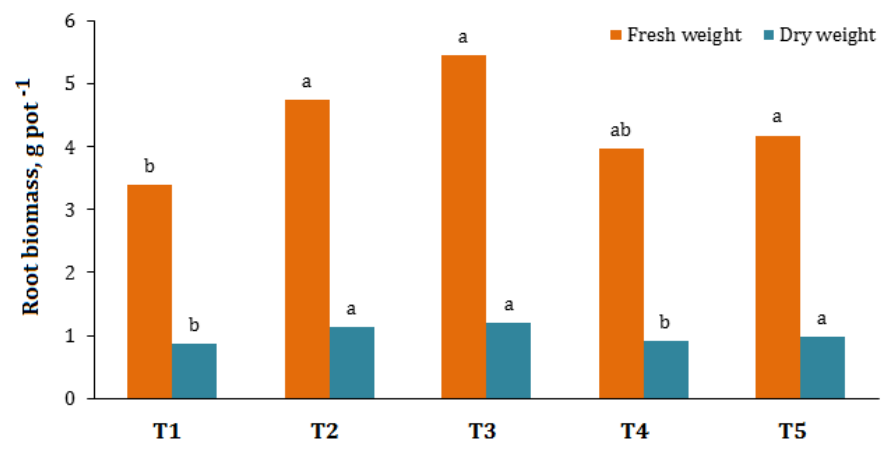

(d)

Figure 2. The effect of different treatments on nutrient content and yield of wheat plant

Fresh and dry weights of shoot and root biomass were significantly affected by the different treatments. Fresh weights of wheat plant ranged from $9.1 \mathrm{~g}$ in control treatment to $19.09 \mathrm{~g}$ in T3. Dry weight of the plants was the lowest in control plant with a value of $1.87 \mathrm{~g}$ whereas all other treatments had higher dry weight values than control statistically (Figure 2c).

Root biomass was significantly affected by the treatments $(\mathrm{P}<0.05)$ and followed a similar trend with shoot biomass. Fresh weight of root biomass ranged from $3.39 \mathrm{~g}$ to $5.45 \mathrm{~g}$. The highest fresh root weight was determined in T3 which was significantly higher than control treatment, but it was not significantly diferent from the other treatments. Dry weights of the roots varied from $0.86 \mathrm{~g}$ in control to $1.19 \mathrm{~g}$ in T4 (Figure 2d). There was not significant differences for dry root weight among the treatments, except the control. 


\section{Biological properties of rhizosphere and bulk soil}

The effects of different treatments on biological properties of rhizosphere and bulk soils are illustrated in Figure 3. Alkaline phosphatase activity (APA) measured in the treatments varied between 20.1 to $22.76 \mu \mathrm{g}$ pNP $\mathrm{g}^{-1}$ in rhizosphere soil and not significantly differed each other. However treatments significantly affected the APA in bulk soil. The highest APA in bulk soil was detrmined in T5 which was statistically the same with T1, T2 and T4 but different from T3.

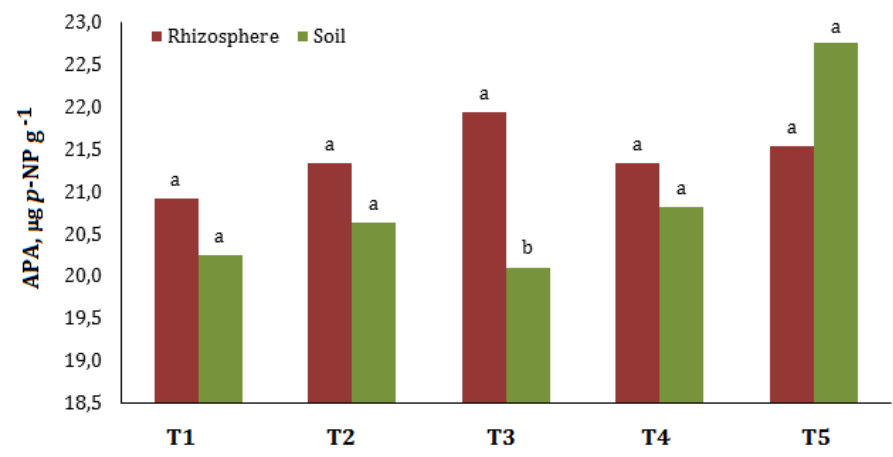

(a)

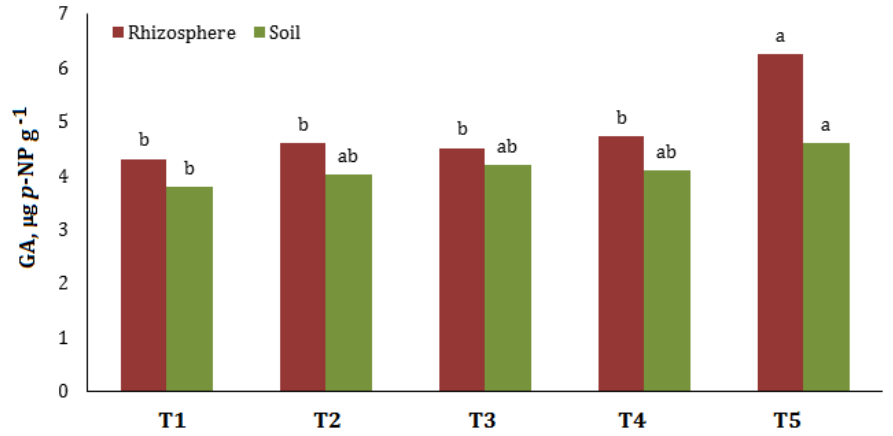

(b)

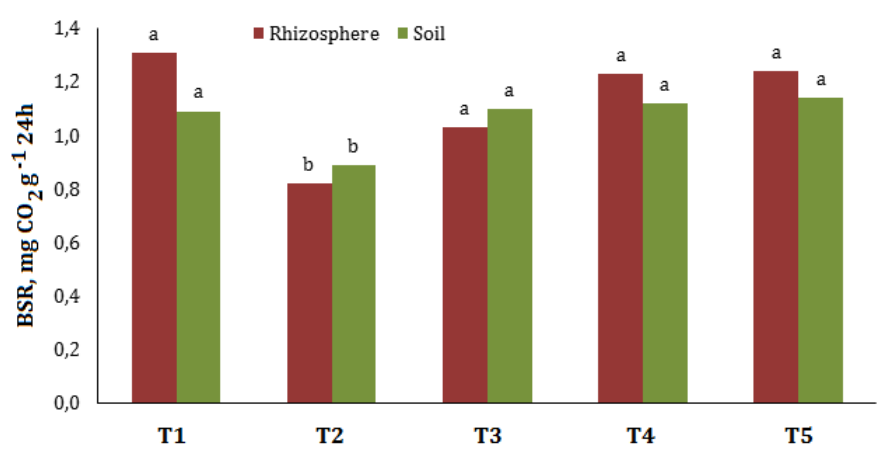

(c)

Figure 3. The effect of different treatments on biological properties of rhizosphere and bulk soils

$\beta$-glucosidase (GA) activity measured in the treatments varried between 3.79 and $6.25 \mathrm{mg}^{\mathrm{pNP}} \mathrm{g}^{-1}$. The highest GA in rhizospere and bulk soils was observed with T5 treatment. In bulk soil, GA increased with T2, T3 and T4 treatments, but they were not different from the control treatment statistically (Figure 3b).

BSR varied between 0.82 and $1.31 \mathrm{mg} \mathrm{CO}_{2} \mathrm{~g}^{-1} 24 \mathrm{~h}^{-1}$. Similar trend was observed in both rhizosphere and bulk soils (Figure 3c). Basal soil respiration (BSR) values in the control treatments were generally higher than that in the other treatments. The lowest BSR, obtained from T2 treatments in rhizospeher and bulk soils, were significantly different from the other treatments. BSR increased with T4 and T5 treatments.

\section{Discussion}

Application of PSB-PGPR has been long reported to enhance soil properties like; nitrogen fixation in soil (Zahid et al., 2015), phosphorus solubility (Khan et al., 2009) and plant growth like agro-morphological parameters (Egamberdieva, 2010), enhanced uptake of nutrients in above ground parts of the plant (Cakmakci et al., 2007; Sarker et al., 2014; Zahid et al., 2015) and physiological parameters (Turan et al., 2014).

A decrease in bulk soil pH was observed in the study by Chen et al. (2006). They reported that application of PSB reduces $\mathrm{pH}$ of the soil in certain conditions due to release of organic acids to solubilize the insoluble phosphorus fixed in soil layers. Other microbial metabolites are also responsible for decreasing the soil $\mathrm{pH}$ (Abd-Alla, 1994), however decrease in bulk or rhizosphere is not always evident. The electrical conductivity of soil also increases with increase in metabolite concentration as observed in this study. Increase in rhizosphere soil nitrogen content with application of PGPR was also observed by Cakmakci et al. (2007). Nitrogen fixation is the ultimate reason behind increased nitrogen concentration in rhizosphere (Saharan and Nehra, 2011). Several free living and symbiotic bacteria enhance nitrogen content of soil in different 
crop conditions. Hussain et al. (2013) observed that phosphate solubilizing bacteria increased phosphatase and organic phosphate mineralization activity in this study, rhizosphere and soil phosphorus content increased with phospahatase activity. Phosphatase activity is considered as main contributor towards increased phosphorus and its availability in the soil (Xu and Johnson, 1995). Certain soil microbes also release organic acids which dissolve the rock phosphate along with chelating the calcium ions which consequently release phosphorus into the soil solution (Saharan and Nehra, 2011).

Bulk soil organic matter almost remained the same in all treatments while SOM content of rhizosphere generally increased by the treatments over the control. The results for rhizosphere SOM were similar to findings of the study by Ul Hassan and Bano (2015). They observed that SOM significantly increased with PGPR bacteria application. Prevention of organic matter due to application of biofertilizers may be the reason for increased SOM in treated pots (Hamuda and Patkó, 2013).

Nitrogen and phosphorus contents in the above ground parts of wheat plants increased significantly in all the treatments, and they were similar to findings of previous studies by Majeed et al. (2015) and Ul Hassan and Bano (2015). Multidimensional roles of PGPR also contribute to enhanced nutrient uptake by plants thus leading to more nitrogen and phosphorus content in above ground plant parts (Kuan et al., 2016). Root growth in response to PGPR bacteria inoculation also leads to better nutrient uptake by the plants (Bhattacharyya and Jha, 2012). Vikram (2007) also reported auxin assisted improvement in roots thus leading to more nitrogen and phosphorus content in above ground plant parts.

Increases in plant root and shoot biomass were observed in different crops in response to PGPR bacteria as witnessed in this study (Yildirim et al., 2008, 2011a, 2011b; Turan et al., 2014). Different plant growth promoting characteristics of PGPR bacteria and PSB are linked to enhanced plant growth in wheat plants (Salantur et al., 2006). Gianfreda (2015) reported that soil enzyme activities and respiration give an idea about microbial population and functioning in the soil where enzyme measurement in the soil also defines health of the plants. Gianfreda (2015) determined that enzyme activity is higher in rhizosphere soil when compared to bulk soil which is similar to the results of this study. Hamuda and Patkó (2013) found similar results and observed that when soil was augmented with microbes along with NPK had higher enzyme activities compared with sterile soils. Roca etal. (2013) indicated that the logic behind higher alkaline phosphatase enzyme activity is presence of insoluble phosphate for which PSB can produce enzymes and organic acids to solubilize this unavailable phosphorus. Dinesh et al. (2013) determined that application of PGPR bacteria and chemical fertilizers activates soil enzymes on different levels. They concluded that soil biological activities are activated and increased due to application of chemical and biological fertilizers.

\section{Conclusion}

Treatments had no or minimum effects on agro-morphological parameters, but had more prominent effects on soil biological properties. Application of raw phosphate enhanced phosphate solubilizing bacterial activity and showed more enzyme activities along with soil respiration. Similarly, application of PSB-PGPR like in T4 treatment also showed increase in soil biological properties, but absence of substrate like raw phosphate did not enhance biological properties when compared with other treatments. Differences between rhizosphere and bulk soil were observed in few soil parameters. The effects of treatments on soil properties were minimum in bulk soil and more in rhizosphere soil.

\section{Acknowledgements}

The authors thank Mehmet Ogut for the support of his bacteria strains and contribution to the planning of this work.

\section{References}

Abd-Alla, M.H., 1994. Phosphatases and the utilization of organic phosphorus by Rhizobium leguminosarum biovar viceae. Letters in Applied Microbiology 18(5): 294-296.

Afsal, A., Bano, A., 2008. Rhizobium and phosphate solubilizing bacteria improve the yield and phosphorus uptake in wheat (Triticum aestivum). International Journal of Agriculture and Biology 10(1): 85-88.

Akça, M.O., Namll, A., 2015. Effects of poultry litter biochar on soil enzyme activities and tomato, pepper and lettuce plants growth. Eurasian Journal of Soil Science 4(3): 161-168.

Ananyeva, N.D., Rogovaya, S.V., Ivashchenko, K.V., Vasenev, V.I., Sarzhanov, D.A., Ryzhkov, O.V., Kudeyarov, V.N., 2016. Carbon dioxide emission and soil microbial respiration activity of Chernozems under anthropogenic transformation of terrestrial ecosystems. Eurasian Journal of Soil Science 5(2): 146 - 154. 
Așkın, T., Kızılkaya, R., 2006. Assessing spatial variability of soil enzyme activities in pasture topsoils using geostatistics. European Journal of Soil Biology 42(4): 230-237.

Bartholdy, B.A., Berreck, M., Haselwandter, K., 2001. Hydroxamate siderophore synthesis by Phialocephala fortinii, a typical dark septate fungal root endophyte. Biometals 14(1):33-42.

Bhattacharyya, P.N., Jha, D.K., 2012. Plant growth-promoting rhizobacteria (PGPR): emergence in agriculture. World Journal of Microbiology and Biotechnology 28(4): 1327-1350.

Bishop, M.L., Chang, A.C., Lee, R.W.K. 1994. Enzymatic mineralization of organic phosphorus in a volcanic soil in Chile. Soil Science 157(4): 238-243.

Cakmakci, R., Dönmez, M.F., Erdoğan, Ü., 2007. The effect of plant growth promoting rhizobacteria on barley seedling growth, nutrient uptake, some soil properties, and bacterial counts. Turkish Journal of Agriculture and Forestry 31(3): 189-199.

Calvo, P., Ormeño-Orrillo, E., Martínez-Romero, E., Zúñiga, D., 2010. Characterization of Bacillus isolates of potato rhizosphere from andean soils of Peru and their potential PGPR characteristics. Brazilian Journal of Microbiology 41(4): 899-906.

Caravaca, F., Figueroa, D., Roldán, A., Azcón-Aguilar, C., 2003. Alteration in rhizosphere soil properties of afforested Rhamnus lycioides seedlings in short-term response to mycorrhizal inoculation with Glomus intraradices and organic amendment. Environmental Management 31(3): 412-420.

Chen, Y.P., Rekha, P.D., Arun, A.B., Shen, F.T., Lai, W.A., Young, C.C., 2006. Phosphate solubilizing bacteria from subtropical soil and their tricalcium phosphate solubilizing abilities. Applied Soil Ecology 34(1): 33-41.

Dinesh, R., Anandaraj, M., Kumar, A., Srinivasan, V., Bini, Y.K., Subila, K.P., Aravind, R., Hamza, S., 2013. Effects of plant growth-promoting rhizobacteria and NPK fertilizers on biochemical and microbial properties of soils under ginger (Zingiber officinale) cultivation. Agricultural Research 2(4): 346-353.

Egamberdieva, D., 2010. Growth response of wheat cultivars to bacterial inoculation in calcareous soil. Plant, Soil and Environment 56: 570-573.

Gianfreda, L., 2015. Enzymes of importance to rhizosphere processes. Journal of Soil Science and Plant Nutrition 15(2): 283-306.

Glick, B.R., Cheng, Z., Czarny, J., Duan, J., 2007. Promotion of plant growth by ACC deaminase-producing soil bacteria. European Journal of Plant Pathology 119(3): 329-339.

Goldstein, A. H. 1994. Involvement of the quinoprotein glucose dehydrogenises in the solubilization of exogenous phosphates by gram-negative bacteria. In: Phosphate in Microorganisms: Cellular and Molecular Biology, Torriani Gorini, A., Yagil, E., Silver, S. (Eds.). ASM Press, Washington DC, USA. pp. 197-203.

Gupta, N., Sabat, J., Parida, R., Kerkatta, D., 2007. Solubilization of tricalcium phosphate and rock phosphate by microbes isolated from chromite, iron and manganese mines. Acta Botanica Croatica 66(2): 197-204.

Hamadali, H., Hafidi, M., Virolle, M.J.., Ouhdouch, Y., 2008. Rock phosphate solubilizing actinomycetes: screening for plant growth promoting activities. World Journal of Microbiology and Biotechnology 24(11): 2565-2575.

Hamuda, H., Patkó, I., 2013. PGPR strains selection to improve plant productivity and soil quality. In: International Scientific-Practical Conference, Food, Technologies and Health 2013. 7-8 November 2013, Plovdiv, Bulgaria, Food Research and Development Institute, pp. 44-50.

Hinsinger, P., Bravin, M. N., Devau, N., Gerard, F., Le Cadre, E., \& Jaillard, B. 2008. Soil-root microbe interactions in the rhizosphere: A key to understanding and predicting nutrient bioavailability to plants. Journal of Soil Science and Plant Nutrition 8:39-47.

Hussain, M.I., Asghar, H.N., Akhtar, M.J., Arshad, M., 2013. Impact of phosphate solubilizing bacteria on growth and yield of maize. Soil \& Environment 32(1):71-78.

Karaca, A., Çetin, S.C., Turgay, O.C., Kızılkaya, R., 2011. Soil enzymes as indication of soil quality. In: Soil Enzymology, Soil Biology. Girish, S. Varma, A., (Eds.). Vol 22, Springer-Verlag Berlin Heidelberg. pp.119-148.

Khan, A.A., Jilani, G., Akhtar, M.S., Naqvi, S.M.S., Rasheed, M., 2009. Phosphorus solubilizing bacteria: occurrence, mechanisms and their role in crop production. Journal of Agricultural and Biological Sciences 1: 48-58.

Khan, M.S., Zaidi, A., Ahmad, E., 2014. Mechanism of phosphate solubilization and physiological functions of phosphatesolubilizing microorganisms. In: Phosphate solubilizing microorganisms: Principles and application of microphos technology. Khan, M.S., Zaidi, A., Musarrat, J. (Eds.). Springer, Switzerland, pp. 31-62.

Kızılkaya, R., Aşkın, T., Bayraklı, B., Sağlam, M., 2004. Microbiological characteristics of soils contaminated with heavy metals. European Journal of Soil Biology 40(2): 95-102.

Kizlkaya, R., Bayraklı, B., 2005. Effects of N-enriched sewage sludge on soil enzyme activities. Applied Soil Ecology 30(3): 192-202.

Kohler, J., Caravaca, F., Carrasco, L., Roldán, A., 2007. Interactions between a plant growth-promoting rhizobacterium, an AM fungus and a phosphate-solubilising fungus in the rhizosphere of Lactuca sativa. Applied Soil Ecology 35(3): 480-487.

Kuan, K.B., Othman, R., Abdul Rahim, K., Shamsuddin, Z.H., 2016. Plant growth-promoting rhizobacteria inoculation to enhance vegetative growth, nitrogen fixation and nitrogen remobilisation of maize under greenhouse conditions. PLOS ONE 11(3): e0152478. 
Lipping, Y., Jiatao, X., Daohong, J., Yanping, F., Guoqing, L., Fangcan, L., 2008. Antifungal substances produced by Penicillium oxalicum strain PY-1-potential antibiotics against plant pathogenic fungi. World Journal of Microbiology and Biotechnology 24(7): 909-915.

Majeed, A., Abbasi, M.K., Hameed, S., Imran, A., Rahim, N., 2015. Isolation and characterization of plant growthpromoting rhizobacteria from wheat rhizosphere and their effect on plant growth promotion. Frontiers in Microbiology 6: 198.

Maliha, R., Khalil, S., Ayub, N., Alam, S., Latif, S., 2004. Organic acids production and phosphate solubilizaion by microorganisms (PSM) under in vitro conditions. Pakistan Journal of Biological Sciences 7(2): 187-196.

Mehrvarz, S., Chaichi, M.R., Alikhani, H.A., 2008. Effects of phosphate solubilizing microorganisms and phosphorus chemical fertilizer on yield and yield components of barely (Hordeum vulgare L.). American- Eurasian Journal of Agricultural Environmental Sciences 3(6): 822-828.

Mullen, M.D., 2005. Phosphorus in soils: Biological interactions. In: Encyclopedia of Soils in the Environment, Hillel, D., (Ed.). Elsevier, pp. 210-215.

Naseby, D.C., Lynch, J.M., 1997. Rhizosphere soil enzymes as indicators of perturbations caused by enzyme substrate addition and inoculation of a genetically modified strain of Pseudomonas fluorescens on wheat seed. Soil Biology and Biochemistry 29(9-10): 1353-1362.

Naseby, D.C., Moënne-Loccoz, Y., Powell, J., O‘Gara, F., Lynch, J.M., 1998. Soil enzyme activities in the rhizosphere of field-grown sugar beet inoculated with the biocontrol agent Pseudomonas fluorescens F113. Biology and Fertility of Soils 27(1): 39-43.

Ogut, M., Er, F., 2016.Mineral composition of field grown winter wheat inoculated with phosphorus solubilizing bacteria at different plant growth stages. Journal of Plant Nutrition 39(4): 479-490.

Ogut, M., Er, F., Kandemir, N., 2010. Phosphate solubilization potentials of soil Acinetobacter strains. Biology and Fertility of Soils 46(7): 707-715.

Roca, A., Pizarro-Tobías, P., Udaondo, Z., Fernández, M., Matilla, M.A., Molina-Henares, M.A., Molina, L., Segura, A., Duque, E., Ramos, J.L., 2013. Analysis of the plant growth-promoting properties encoded by the genome of the rhizobacterium Pseudomonas putida BIRD-1. Environmental Microbiology 15(3): 780-794.

Rowell, D.L., 1996. Soil Science: Methods and Applications. $3^{\text {rd }}$ Edition Longman. London, UK.

Ryan, J., Estefan, G., Rashid, A., 2001. Soil and plant analysis laboratory manual. International Center for Agricultural Research in the Dry Areas (ICARDA). Syria.

Saharan, B.S., Nehra, V., 2011. Plant growth promoting rhizobacteria: a critical review. Life Sciences and Medicine Research Volume 2011: LSMR-21

Salantur, A., Ozturk, A., Akten, S., 2006. Growth and yield response of spring wheat (Triticum aestivum L.) to inoculation with rhizobacteria. Plant, Soil and Environment 52: 111-118.

Sarker, A., Talukder, N.M., Islam, Md.T., 2014. Phosphate solubilizing bacteria promote growth and enhance nutrient uptake by wheat. Plant Science Today 1(2): 86-93.

Sharma, S.B., Sayyed, R.Z., Trivedi, M.H., Gobi, T.A., 2013. Phosphate solubilising microbes: sustainable approach for managing phosphorus deficiency in agricultural soils. SpringerPlus 2:587.

Sharma, S.K., Johri, B.N., Ramesh, A., Joshi, O.P., Prasad, S.S., 2011. Selection of plant growth-promoting Pseudomonas spp. that enhanced productivity of soybean-wheat cropping system in central India. Journal of Microbiology and Biotechnology 21(11): 1127-1142.

Shenoy,V.V., Kalagudi, G.M., 2005. Enhancing plant phosphorus use efficiency for sustainable cropping. Biotechnology Advances 23(7-8): 501-513.

Singh, N., Kumar, S., Bajpai, V.K., Dubey, R.C., Maheshwari, D.K., Kang, S.C., 2010. Biological control of Macrophomina phaseolina by chemotactic fluorescent Pseudomonas aeruginosa PN1 and its plant growth promotory activity in chir-pine. Crop Protection 29(10): 1142-1147.

Son, T.T.N., Diep, C.N., Giang, T.T.M., 2006. Effect of bradyrhizobia and phosphate solubilizing bacteria application on soybean in rotational system in the Mekong delta. Omonrice 14: 48-57.

Song, O.R., Lee, S.J., Lee, Y.S., Lee, S.C., Kim, K.K., Choi, Y.L., 2008. Solubilization of insoluble inorganic phosphate by Burkholderia cepacia DA 23 isolated from cultivated soil. Brazil Journal of Microbiology 39(1): 151-156.

Souchie, E.L., Azcón, R., Barea, J.M., Saggin-Júnior, O.J., da Silva, E.M.R., 2007. Indolacetic acid production by Psolubilizing microorganisms and interaction with arbuscular mycorrhizal fungi. Acta Scientiarum Biological Sciences 29: 315-320.

Tank, N., Saraf, M., 2003. Phosphate solubilization, exopolysaccharide production and indole acetic acid secretion by rhizobacteria isolated from Trigonella graecum. Indian Journal of Microbiology 43(1): 37-40.

Taurian, T., Anzuay, M.S., Angelini, J.G., Tonelli, M.L., Ludueña, L., Pena, D., Ibáñez, F., Fabra, A., 2010. Phosphatesolubilizing peanut associated bacteria: screening for plant growth-promoting activities. Plant and Soil 329(1): 421-431.

Toro, M., 2007. Phosphate solubilizing microorganisms in the rhizosphere of native plants from tropical savannas: An adaptive strategy to acid soils? In: Developments in Plant and Soil Sciences. Velaquez, C., Rodriguez-Barrueco, E., (Eds.). Springer, The Netherlands. pp. 249-252. 
Trivedi, P., Sa, T. 2008. Pseudomonas corrugata (NRRL B-30409) mutants increased phosphate solubilization, organic acid production and plant growth at lower temperatures. Current Microbiology 56(2): 140-144.

Turan, M., Ekinci, M., Yildirim, E., Güneş, A., Karagöz, K., Kotan, R., Dursun, A. 2014. Plant growth-promoting rhizobacteria improved growth, nutrient, and hormone content of cabbage (Brassica oleracea) seedlings. Turkish Journal of Agriculture and Forestry 38: 327-333.

Ul Hassan, T., Bano, A., 2015. The stimulatory effects of L-tryptophan and plant growth promoting rhizobacteria (PGPR) on soil health and physiology of wheat. Journal of Soil Science and Plant Nutrition 15(1): 190-201.

Vassilev, N., Vasileva, M.A., Nikolaeva, L., 2006. Simultaneous P solubilizing and biocontrol activity of microorganisms: potentials and future trends. Applied Microbiology and Biotechnology 71(2): 137-144.

Vikram, A., Alagawadi, A.R., Hamzehzarghani, H., Krishnaraj, P.U., 2007. Factors related to the occurrence of phosphate solubilizing bacteria and their isolation in vertisols. International Journal of Agricultural Research 2(7): 571-580.

Walker, J.D., Enache, M., Dearden, J.C.. 2003. Quantitative cationic activity relationships for predicting toxicity of metal ions from physicochemical properties and natural occurrence levels. QSAR \& Combinatorial Science 26(4): 522527.

Wang, X., Tang, C., Guppy, C.N., Sale, P.W.G., 2009. The role of hydraulic lift and subsoil P placement in P uptake of cotton (Gossypium hirsutum L.). Plant and Soil 325(1): 263-275.

Wani, P.A., Khan, M.S., Zaidi, A., 2007a. Co-inoculation of nitrogen fixing and phosphate solubilizing bacteria to promote growth, yield and nutrient uptake in chickpea. Acta Agronomica Hungarica 55(3): 315-323.

Wani, P.A., Khan, M.S., Zaidi, A. 2007b. Synergistic effects of the inoculation with nitrogen fixing and phosphate solubilizing rhizobacteria on the performance of field grown chickpea. Journal of Plant Nutrition and Soil Science 170(2): 283-287.

Wani, P.A., Khan, M.S., Zaidi, A., 2008. Chromium-reducing and plant growth-promoting Mesorhizobium improves chickpea growth in chromium-amended soil. Biotechnology Letters 30(1): 159-163.

Xu, J.G., Johnson, R.L., 1995. Root growth, microbial activity and phosphatase activity in oil-contaminated, remediated and uncontaminated soils planted to barley and field pea. Plant and Soil 173(1): 3-10.

Yildirim, E., Turan, M., Donmez, M.F., 2008. Mitigation of salt stress in radish (Raphanus sativus L.) by plant growth promoting rhizobacteria. Roumanian Biotechnological Letters 13(5): 3933-3943.

Yildirim, E., Karlidag, H., Turan, M., Dursun, A., Goktepe, F., 2011a. Growth, nutrient uptake, and yield promotion of broccoli by plant growth promoting rhizobacteria with manure. HortScience 46(6): 932-936.

Yildirim, E., Turan, M., Ekinci, M., Dursun, A., Çakmakçı, R. 2011b. Plant growth promoting rhizobacteria ameliorate deleterious effect of salt stress on lettuce. Scientific Research and Essays 6(20): 4389-4396.

Zahid, M., Abbasi, M.K., Hameed, S., Rahim, M. 2015. Isolation and identification of indigenous plant growth promoting rhizobacteria from Himalayan region of Kashmir and their effect on improving growth and nutrient contents of maize (Zea mays L.). Frontiers in Microbiology 6: 207. 